\title{
POSTEROLATERAL ARTHRODESIS AND INTERBODY ARTHRODESIS FOR LUMBAR CANAL STENOSIS
}

\author{
ARTRODESE POSTEROLATERAL E ARTRODESE INTERSOMÁTICA \\ PARA ESTENOSE DE CANAL LOMBAR
}

\author{
Oswaldo Roberto Nascimento ${ }^{1}$, Leonardo Yukio Jorge Asano ${ }^{1}$, André Nunes Machado ${ }^{1}$, André Evaristo Marcondes Cesar ${ }^{1}$, \\ LUCIANo MILLER ReIS RodRIGUeS ${ }^{1}$
}

1. Faculdade de Medicina do ABC, Spine Surgery Group, Santo André, SP, Brazil.

\begin{abstract}
Objectives: To compare the clinical outcomes and quality of life of patients surgically treated for lumbar spinal stenosis with decompression and posterolateral fusion, and decompression with interbody fusion. Methods: The study included 88 patients with lumbar canal stenosis who underwent surgery treatment (decompression and interbody fusion in 36 patients and decompression and posterolateral fusion [PL] in 52 patients). The clinical outcomes were assessed using the Oswestry Disability Index (ODI), Roland-Morris (RM) functional disability scale, and visual analog scale (VAS) for pain. These questionnaires were administered preoperatively and 1 month, 6 months, 1 year, and 2 years postoperatively. Results: Eighty-eight patients had surgery 2 years prior. The ODI and RM scale scores showed significant differences in the posterolateral group. In the interbody group, the ODI score showed a significant change only from before to 1 and 2 years after surgery. The VAS score significantly changed only from before to after surgery in the posterolateral group, but in the interbody group, the change was also observed at 1 month and 1 year after surgery. Conclusions: The two techniques are effective surgical treatment options for lumbar canal stenosis as long as they are well indicated. Level of evidence III, Comparative prospective case-control study.
\end{abstract}

Keywords: Spinal stenosis. Spinal fusion. Quality of life.

\section{RESUMO}

Objetivos: Comparar os desfechos clínicos e a qualidade de vida dos pacientes tratados cirurgicamente de estenose de coluna lombar por descompressão e fusão posterolateral e por descompressão e fusão intersomática. Métodos: O estudo incluiu 88 pacientes com estenose de canal lombar submetidos a tratamento cirúrgico (descompressão e fusão intersomática em 36 pacientes e descompressão e fusão posterolateral [PL] em 52 pacientes). Os desfechos clínicos foram avaliados pelo Índice de Incapacidade de Oswestry (ODI), Questionário de Incapacidade Roland-Morris (RM) e pela escala visual analógica (VAS) para dor. Esses questionários foram administrados no pré-operatório e 1 mês, 6 meses, 1 ano e 2 anos depois da cirurgia. Resultados: Oitenta e oito pacientes foram operados dois anos antes. Os escores do ODI e do questionário RM mostraram diferenças significantes no grupo posterolateral. No grupo intersomático, o escore do ODI mostrou alteração significante somente antes da cirurgia e 1 e 2 anos depois dela. O escore da VAS mudou significativamente só de antes da cirurgia para depois dela no grupo posterolateral, porém, no grupo intersomático, a alteração foi verificada também 1 mês e 1 ano depois da cirurgia. Conclusões: As duas técnicas são opções eficazes de tratamento cirúrgico da estenose de canal lombar, desde que sua indicação seja correta. Nível de evidência III, Estudo prospectivo comparativo de caso-controle.

Descritores: Estenose espinal. Fusão vertebral. Qualidade de vida.

Citation: Nascimento OR , Asano LYJ, Machado AN, Cesar AEM, Rodrigues LMR. Posterolateral arthrodesis and interbody arthrodesis for lumbar canal stenosis. Acta Ortop Bras. [online]. 2019;27(1):38-41. Available from URL: http://www.scielo.br/aob.

\section{INTRODUCTION}

Degenerative joint disease is the leading cause of chronic disability all over the world and usually presents with joint pain, tenderness, stiffness, locking, and effusion. ${ }^{1}$ Lumbar degenerative disease is the most frequent and fast growing reason of spinal surgeries on patients over 65 years old, and fusion is often necessary. ${ }^{2,3}$ The rate of lumbar fusion increases ten times faster than other orthopaedics procedures like total hip or knee replacement. ${ }^{2}$ One consequence of the degeneration is the stenosis. The narrowing of the spinal canal which causes spinal cord compression, or stenosis of the lumbar canal, was first described by Verbiest in 1954. ${ }^{4}$ According to the author, the symptoms of the nerve roots compression due to hypertrophy of the articular processes occurred when the patient was in the upright position and mainly walking. Further studies described compression of nervous structures due

All authors declare no potential conflict of interest related to this article.

Study was conducted at the Faculdade de medicina do ABC, Santo André, SP, Brazil.

Correspondence: Av. Príncipe de Galés, 821 Vila Príncipe de Gales, Santo André, SP 09060-650, Brasil. luciano.miller@uol.com.br 
to other components such as hypertrophy of the yellow ligament, synovial cyst facet, and loss of height of the intervertebral disc. ${ }^{5}$ Patients with spinal canal compression will complaint of neurogenic claudication with or without radicular pain. When symptomatic patients with stenosis confirmed by imaging, tomography and lumbar $\mathrm{MRI}$, should initially be treated conservatively with physical therapy, pain medication and foraminal injection. ${ }^{6}$ Surgical decompression is indicated when conservative treatment fails, when the patient developed cauda equina or progressive motor deficit. ${ }^{7}$

Lumbar arthrodesis is needed when there is instability and can be accomplished through posterolateral fusion (PL), when bone graft is placed between transverse processes, and interbody fusion (IB) technique if the bone graft is put between vertebral bodies. The use of IB fusion is indicated when the origin of pain is the intervertebral disc. $^{8}$ The advantages are better support for the anterior column, indirect foraminal decompression, restoration of lordosis and better removal of an important factor pain that is the intervertebral disc. However this technically is more demanding. ${ }^{9-11}$ When the source of pain is the facet joint, PL fusion is indicated. ${ }^{3}$ This technique is easier to be accomplished and has less complication rate, but generates more pain due to the need for greater exposure and damage to paravertebral muscles. ${ }^{12}$ Despite the tendency nowadays to be the use of IB fusion, there are little support in scientific publications for its superiority. ${ }^{8}$ Numerous studies comparing the different techniques have very broad satisfactory results ranging from 36 to $95 \%$ success rate which leaves the surgeons with no conclusion of the best technique. ${ }^{13}$ This study analises the outcome of these two technique for lumbar stenosis and their impact on the quality of life.

\section{OBJECTIVE}

To compare the clinical and the quality of life of patients surgically treated for lumbar spinal stenosis with two different techniques: decompression with postero-lateral fusion, and decompression with interbody fusion.

\section{MATERIALS AND METHODS}

We was approved by the Medical Ethical Committee of Faculdade de Medicina do ABC (CAAE: 13842913.5.0000.0082). From May 2011 to November 2012, we compared 36 patients who underwent the decompression and interbody fusion (IB) with 52 patients who underwent decompression and postero-lateral fusion (PL). All participants signed the Free and Informed Consent Form.

The inclusion and exclusion criteria and outcome measurements were identical in the 2 groups. All patients had the diagnosis of one-level lumbar canal stenosis in by imaging (plain radiography, dynamic radiography and magnetic resonance of the lumbar spine). They presented neurogenic claudication complaint, functional impairment for more than 6 months and failure of conservative treatment. Exclusion criteria were previous surgery, psychiatric disorders (use of medications for psychiatric disorders or psychiatric monitoring), tumor, infection, myelopathy signs of spinal cord compression.

In both groups the surgeries were performed by two seniors surgeons. All patients were in prone position with general anaesthesia. The incision was longitudinal over the segment affected, confirmed with the aid of fluoroscopy. Posterior decompression, including laminectomy, medial facetectomy, and foraminotomy and pedicle screw fixation were performed in all patients. In the first group, the $\mathrm{PL}$, the graft used was obtained from the lamina removed during surgical decompression. In the IB group, a cage was placed via transforaminal (TLIF), and we used the lamina graft.

During follow-up of patients we used the postoperative generic questionnaires specific for spine surgery, Oswestry Disability In$\operatorname{dex}^{14}(\mathrm{ODI})$ and Roland Morris ${ }^{15}(\mathrm{RM})$. To quantify pain we used the visual analogue pain scale (VAS). These questionnaires were performed preoperatively, after one month, 6 months, 1 year and 2 years postoperative.

Analyses were performed using the SPSS - Statistical Package for Social Sciences (v18.0). For comparisons between categories and points in time, we used Bonferroni post hoc tests due to performing multiple tests. The level of significance was set at 0.05 or $5 \%$.

\section{RESULTS}

We followed a total of 88 patients for 2 years after surgery. The patients characteristics are showed in Table 1. There were 39 females (44.3\%) and 49 males (55.7\%). Fifty two (59.1\%) patients underwent the $\mathrm{PL}$ technique, 27 females and 25 males, and 36 $(40,9 \%)$ the IB, 12 females and 24 males. The mean age was 60.2 years, 62.4 for PL and 58 for IB technique.

The ODI and RM (Table 2) showed diference in PL group when comparing pre-operative with 6 months, 1 year and 2 years, and 1 month with 6 months, 1 year and 2 years. On the IB group (Table 3) the change was seen only on the comparison of ODI score in pre-operative with 1 year and 2 years, but RM only changed comparing per and post-operative moments.

When compared ODI e RM on the both techniques two year after surgery, there was no statistically significant difference. The graphical representation of the relationship between ODI, RM and their respective time points is shown in the Figure $1 \mathrm{e} 2$.

The analogue visual scale (Table 2) changed in the PL group comparing pre and postoperative results only, but for the IB group (Table 3) the change was also comparing 1 month and 1 year. In the prospective analysis, there was a progressive decline in average values. Significant differences were observed between the analyzes statistics between different time points of pain. However, the comparative analysis showed in both groups no statistically significant difference between moments when paired observation after six months.

\section{DISCUSSION}

The lumbar canal stenosis is the most common cause of low back pain and radicular pain in patients after the fifth decade of life..$^{2,3}$ In advanced cases, muscle atrophy, joint instability, or deformity may develop. ${ }^{1}$ The arthritic changes in the spinal column (spondylosis) with involvement of the facet joints and intervertebral discs, in

\begin{tabular}{c|c|c} 
Table 1. Sample Features. & \multicolumn{2}{|c}{60.2} \\
\hline Age (years) & \multicolumn{2}{|c}{58.0} \\
\hline Mean & \multicolumn{2}{|c}{} \\
\hline PL & \multicolumn{2}{|c}{82.4} \\
\hline I & & \\
\hline Total of patients & & $(55,7 \%)$ \\
\hline Gender - $\mathrm{n}(\%)$ & 49 & $(44,3 \%)$ \\
\hline Masculine & 39 & 88 \\
\hline Feminine & & $(48,0 \%)$ \\
\hline Total of patients & & $(52,0 \%)$ \\
\hline Gender - $\mathrm{n}(\%)$ PL technique & 25 & $(59.1 \%)$ \\
\hline Masculine & 27 & \\
\hline Feminine & 52 & $(66,7 \%)$ \\
\hline Total of patients & & $(33,3 \%)$ \\
\hline Gender - $\mathrm{n}$ (\%) IB technique & 24 & $(40,9 \%)$ \\
\hline Masculine & 12 &
\end{tabular}

PL: Posterolateral fusion group. IB: Interbody fusion group. 


\begin{tabular}{|c|c|c|c|c|}
\hline \multirow{2}{*}{\multicolumn{2}{|c|}{$\begin{array}{c}\text { Set of Variables } \\
\text { ODI }\end{array}$}} & \multicolumn{3}{|c|}{ Significance (p) } \\
\hline & & \multirow{2}{*}{$\begin{array}{c}\text { RM } \\
0,022\end{array}$} & \multirow{2}{*}{$\begin{array}{c}\text { VAS } \\
0,003\end{array}$} & \multirow[b]{2}{*}{$<0,001$} \\
\hline Pre & $1 \mathrm{M}$ & & & \\
\hline & $6 \mathrm{M}$ & $<0,001$ & $<0,001$ & $<0,001$ \\
\hline & $1 \mathrm{Y}$ & $<0,001$ & $<0,001$ & $<0,001$ \\
\hline & $2 Y$ & $<0,001$ & $<0,001$ & $<0,001$ \\
\hline \multirow[t]{4}{*}{$1 \mathrm{M}$} & Pre & 0,022 & 0,003 & $<0,001$ \\
\hline & $6 \mathrm{M}$ & $<0,001$ & $<0,001$ & 1,000 \\
\hline & $1 \mathrm{Y}$ & $<0,001$ & $<0,001$ & 1,000 \\
\hline & $2 Y$ & $<0,001$ & $<0,001$ & 1,000 \\
\hline \multirow[t]{4}{*}{$6 \mathrm{M}$} & Pre & $<0,001$ & $<0,001$ & $<0,001$ \\
\hline & $1 \mathrm{M}$ & $<0,001$ & $<0,001$ & 1,000 \\
\hline & $1 \mathrm{Y}$ & 1,000 & 1,000 & 1,000 \\
\hline & $2 Y$ & 1,000 & 1,000 & 1,000 \\
\hline \multirow[t]{4}{*}{$1 \mathrm{Y}$} & Pre & $<0,001$ & $<0,001$ & $<0,001$ \\
\hline & $1 \mathrm{M}$ & $<0,001$ & $<0,001$ & 1,000 \\
\hline & $6 \mathrm{M}$ & 1,000 & 1,000 & 1,000 \\
\hline & $2 Y$ & 1,000 & 1,000 & 1,000 \\
\hline \multirow[t]{4}{*}{$2 Y$} & Pre & $<0,001$ & $<0,001$ & $<0,001$ \\
\hline & $1 \mathrm{M}$ & $<0,001$ & $<0,001$ & 1,000 \\
\hline & $6 \mathrm{M}$ & 1,000 & 1,000 & 1,000 \\
\hline & $1 Y$ & 1,000 & 1,000 & 1,000 \\
\hline
\end{tabular}

Pre: Preoperative period; M: Month; Y: Year; ODI: Oswentry Disability Index; RM: Roland Morris VAS: Visual Analogue Scale

Table 3. Oswentry, Roland Morris and Visual Analogue Scale questionnaires (interbody fusion group)

\begin{tabular}{|c|c|c|c|c|}
\hline \multirow{2}{*}{\multicolumn{2}{|c|}{$\begin{array}{c}\text { Set of Variables } \\
\text { ODI }\end{array}$}} & \multicolumn{3}{|c|}{ Significance (p) } \\
\hline & & \multirow{2}{*}{$\begin{array}{c}\mathbf{R M} \\
0,060 \\
\end{array}$} & \multirow{2}{*}{$\begin{array}{c}\text { VAS } \\
<0,001 \\
\end{array}$} & \multirow[b]{2}{*}{$<0,001$} \\
\hline Pre & $1 \mathrm{M}$ & & & \\
\hline & $6 \mathrm{M}$ & 0,001 & $<0,001$ & $<0,001$ \\
\hline & $1 Y$ & $<0,001$ & $<0,001$ & $<0,001$ \\
\hline & $2 Y$ & $<0,001$ & $<0,001$ & $<0,001$ \\
\hline \multirow[t]{4}{*}{$1 \mathrm{M}$} & Pre & 0,060 & $<0,001$ & $<0,001$ \\
\hline & $6 \mathrm{M}$ & 0,354 & 0,109 & 0,160 \\
\hline & $1 Y$ & 0,006 & 0,006 & $<0,001$ \\
\hline & $2 Y$ & 0,008 & 0,001 & 0,001 \\
\hline \multirow[t]{4}{*}{$6 \mathrm{M}$} & Pre & 0,001 & $<0,001$ & $<0,001$ \\
\hline & $1 \mathrm{M}$ & 0,354 & 0,109 & 0,160 \\
\hline & $1 Y$ & 0,373 & 0,483 & 0,050 \\
\hline & $2 Y$ & 1,000 & 0,131 & 0,098 \\
\hline \multirow[t]{4}{*}{$1 Y$} & Pre & $<0,001$ & $<0,001$ & $<0,001$ \\
\hline & $1 \mathrm{M}$ & 0,006 & 0,006 & $<0,001$ \\
\hline & $6 \mathrm{M}$ & 0,373 & 0,483 & 0,050 \\
\hline & $2 Y$ & 1,000 & 1,000 & 1,000 \\
\hline \multirow[t]{4}{*}{$2 Y$} & Pre & $<0,001$ & $<0,001$ & $<0,001$ \\
\hline & $1 \mathrm{M}$ & 0,008 & 0,001 & 0,001 \\
\hline & $6 \mathrm{M}$ & 0,198 & 0,131 & 0,098 \\
\hline & $1 Y$ & 1,000 & 1,000 & 1,000 \\
\hline
\end{tabular}

Pre: Preoperative period; M: Month; Y: Year; ODI: Oswentry Disability Index; RM: Roland Morris VAS: Visual Analogue Scale.

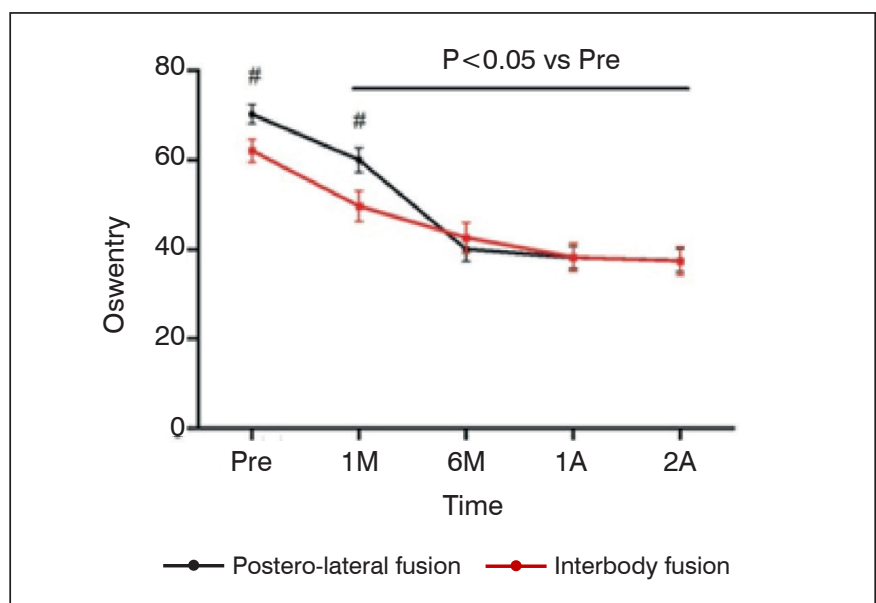

Figure 1.

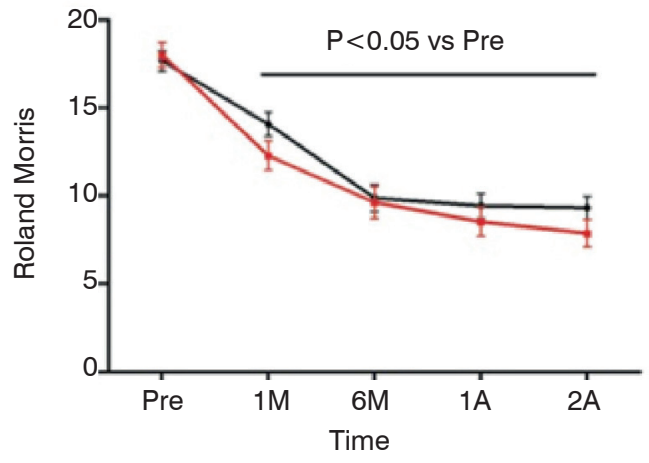

Postero-lateral fusion

ـ Interbody fusion

Figure 1.

addition to these common signs and symptoms, may also cause neurologic impingement. ${ }^{16}$ When surgical treatment is well indicated there are good clinical outcomes. ${ }^{17} \mathrm{PL}$ that fuses the transverse processes and facet joint after decompression has been widely applied, and has had good clinical results and union rates. ${ }^{12}$ PLIF was introduced to address some disadvantages of PL by replacing the disc with an autogenous bone graft or a cage. ${ }^{12}$

Posterolateral lumbar arthrodesis includes fusion of bilateral transverse processes with fusion rate of $81-100 \%$ and clinical success rate of $60-98 \%$. Circumferential fusion has fusion rate varying from 74 to $98 \%$ in adult with spondylolisthesis. ${ }^{18} \mathrm{~A}$ multicenter randomized study compared surgical procedures in 211 patients aged 25-65 and showed no significant difference in clinical outcome after two years. ${ }^{19}$ Despite the fact that the current study was not randomised, the inclusion and exclusion criteria were the same in both groups. We showed that, regardless of the technique performed, good results were obtained.

The study showed that there was no improvement immediately after the surgery in the PL and IB groups, but after 6 months in the first group and only after 1 year in the second group the difference was seen. The RM results showed improvement at all periods postoperative when compared to the pre op period in the both groups. The ODI and RM are specific questionnaires for postoperative spine surgery. At high levels of disability, the ODI may still show change 
when RM scores are maximal, at the other end of the scale, RM scores may still discriminate when ODI scores are at a minimum. Therefore it is recommended to use the ODI in patients who are likely to have persistent severe disability and the RM in patients who are likely to have relatively little disability. ${ }^{20}$ Our patients have, in general, very advanced disease due to long waiting list for surgery, witch can explain the more sensitive results in the ODI questionnaire. The VAS scale has shown the patients have less pain after surgery, fulfilling its purpose. In the IB group there is another improvement after 1 year when comparing to 1 month. This observation can be explained by an indirect decompression of the intervertebral foramen to introduce the cage. This theoretical advantage of interbody fusion can be the cause of the pain improvement in the IB group.

\section{CONCLUSION}

With this study, we can conclude that the two techniques are effectives options for surgical treatment for stenosis of the lumbar canal, as long as it is well indicated. In both procedures, there was a gradual and statistically significant improvement in questionnaires studied for up to 1 year, with maintenance of the índices at two year follouw-up.

AUTHORS' CONTRIBUTIONS: Each author contributed individually and significantly to the development of the manuscript. ORN (0000-0002-9873-8876)* and ANM (0000-0001-8679-1859) monitored patients and collected clinical data. AEMC (0000-0002-0148-4372)* and LYJA (0000-0002-8489-5256)* were the main contributors in writing the manuscript and evaluated the data from the statistical analysis. LMRR (0000-0001-6891-5395)* conducted the bibliographic research and revised the manuscript, and contributed to the intellectual conceptualization of the study. *ORCID (Open Researcher and Contributor ID).

\section{REFERENCES}

1. Omidi-kashani F, Hasankhani EG, Ashjazadeh A. Lumbar Spinal Stenosis: Who Should Be Fused? An Updated Review. 2014;8(4):521-230.

2. Deyo RA, Gray DT, Kreuter W, Mirza S, Martin BI. United States trends in lumbar fusion surgery for degenerative conditions. Spine (Phila Pa 1976). 2005;30(12):1441-5.

3. Gibson JNA, Waddell G. Surgery for degenerative lumbar spondylosis. Cochrane Database Syst Rev. 2005;30(20):CD001352.

4. Verbiest H. A Radicular Syndrome From Developmental Narrowing of the Lumbar Vertebral Canal. J Bone Joint Surg Br. 1954;36-B(2):230-7.

5. Singh K, Samartzis D, Biyani A, An HS. Lumbar spinal stenosis. J Am Acad Orthop Surg. 2008;16:171-6.

6. Siebert E, Prüss H, Klingebiel R, Failli V, Einhäupl KM, Schwab JM. Lumbar spinal stenosis: syndrome, diagnostics and treatment. Nat Rev Neurol. 2009;5(7):392-403.

7. Phillips FM, Slosar PJ, Youssef JA., Andersson GB, Papatheofanis FJ. Clinical Review of Lumbar Spine Fusion for Chronic Low Back Pain Due to Degenerative Disc Disease. Spine J. 2012;12(7):S147-8.

8. Fritzell P, Hagg O, Wessberg P, Nordwall A. Chronic low back pain and fusion: A comparison of three surgical techniques - A prospective multicenter randomized study from the Swedish Lumbar Spine Study Group. Spine (Phila Pa 1976). 2002;27(11):1131-41.

9. Barrick WT, Schofferman JA, Reynolds JB, Goldthwaite ND, McKeehen M, Keaney D, et al. Anterior lumbar fusion improves discogenic pain at levels of prior posterolateral fusion. Spine (Phila Pa 1976). 2000;25(7):853-7.

10. Dehoux E, Fourati E, Madi K, Reddy B, Segal P. Posterolateral versus interbody fusion in isthmic spondylolisthesis: Functional results in 52 cases with a minimum follow-up of 6 years. Acta Orthop Belg. 2004;70(6):578-82.
11. Freeman BJ, Licina $P$, Mehdian SH. Posterior lumbar interbody fusion combined with instrumented postero-lateral fusion: 5-year results in 60 patients. Eur Spine J. 2000;9(1):42-6.

12. Kim K-T, Lee S-H, Lee Y-H, Bae S-C, Suk K-S. Clinical outcomes of 3 fusion methods through the posterior approach in the lumbar spine. Spine (Phila Pa 1976). 2006;31(12):1351-7.

13. Turner JA, Ersek M, Herron L, Deyo R. Surgery for lumbar spinal stenosis. Attempted meta-analysis of the literature. Spine (Phila Pa 1976). 1992;17(1):1-8

14. Fairbank JC, Pynsent PB. The Oswestry Disability Index. Spine (Phila Pa 1976). 2000;25(22):2940-52.

15. Dunn KM, Cherkin DC. The Roland-Morris Disability Questionnaire. Spine (Phila Pa 1976). 2007;32(24):287.

16. Goh KJ, Khalifa W, Anslow P, Cadoux-Hudson T, Donaghy M. The Clinical Syndrome Associated with Lumbar Spinal Stenosis. Eur Neurol. 2004;52(2):242-9.

17. Bjarke Christensen F, Stender Hansen E, Laursen M, Thomsen K, Bünger CE. Long-term functional outcome of pedicle screw instrumentation as a support for posterolateral spinal fusion: randomized clinical study with a 5-year follow-up Spine (Phila Pa 1976). 2002;27(12):1269-77.

18. Kwon BK, Hilibrand AS, Mallory K, Savas PE, Silva MT, Albert TJ, et al. A critical analysis of the literature regarding surgical approach and outcome for adult low-grade isthmic spondylolisthesis. J Spinal Disord Tech. 2005;18 Suppl:S30-40.

19. Fritzell $P$, Hãgg $O$, Nordwall A. Complications in lumbar fusion surgery for chronic low back pain: comparison of three surgical techniques used in a prospective randomized study. A report from the Swedish Spine Study Group. Eur Spine J. 2003;12(2):178-89.

20. Roland MFJ. The Roland - Morris Disability Questionnaire and the Oswestry Disability Questionnaire. Spine (Phila Pa 1976). 2000;25(24):1994. 